\title{
A Structural Equation Model for Analyzing the Impact of Environmental Turbulence on Non-Financial Performance
}

\author{
Zaina Mustafa Mahmoud Hamad ${ }^{1}$ \\ ${ }^{1}$ Business Administration, Faculty of Economics and Administrative Sciences, Okan University, Istanbul, Turkey; \\ Jordan \\ Correspondence: Zaina Mustafa Mahmoud Hamad, PhD Student, Business Administration, Faculty of Economics \\ and Administrative Sciences, Okan University, Istanbul, Turkey; Jordan. E-mail: zeinamustafa1414@yahoo.com
}

Received: April 17, 2016

Accepted: May 4, 2016

Online Published: May 13, 2016

doi:10.5430/jms.v7n2p53

URL: http://dx.doi.org/10.5430/jms.v7n2p53

\begin{abstract}
Environmental turbulence monitoring mechanisms have been acclaimed in the practitioner and academic literature for their potential to improve organizational performance. And because of the limited previous studies in Middle East area addressing the concept of environmental turbulence (ET) as a whole, and precisely the relation between ET and Non-financial performance (NFP) in mobile telecommunications (TLC) sector;

The study aimed to investigate the impact of ET on NFP at firms of Mobile TLC sector in Jordan. To clarify this relationship among their constructs, a Structural Equation Model (SEM) was conducted to examine the model fit and hypotheses.

Study population consisted of all firms of Mobile TLC sector in Jordan (ORANGE, UMNIAH and ZAIN). Study sample included all mobile TLC firms in Jordan (the three firms). The Unit of Sampling and Analysis included all managers, assistant managers and heads of departments working within these firms. Descriptive analytical method was used and a questionnaire was constructed for data collection.

A number of results were reached: there was a significant impact of ET (Technological Turbulence \& Competitive Intensity) on NFP, a significant impact of ET (Market Turbulence \& Competitive Intensity) on Customer Satisfaction, and a significant impact of ET (Technological Turbulence \& Competitive Intensity) on Market Effectiveness at Jordanian Mobile TLC firms.

The study recommended the need for firms under study to enhance the role of environmental screening of the external environment on ongoing basis to keep pace with technological changes, as well as the competition intensity in the Mobile TLC field environment.
\end{abstract}

Keywords: environmental turbulence, non-financial performance, mobile TLC sector, structural equation model

\section{Introduction}

All the humanitarian organizations with their different types and multiple objectives were characterized by being open organizations interact with the surrounding environment especially that type of the environment or that environmental variables relating to the organization.

Also, all these organizations are subject to the limitations of that environment, so we find that these organizations represented by its managements working hard and in all means and ways to know the environment and to investigate and follow up its variables movements and studying these variables in order to respond to it.

The organizations managements monitor the environmental changes and work to adapt with it through creating internal changes corresponded with the external changes as possible through the fit between the strengths and weakness in the organization and the different trends in the environment represented by the opportunities and threats since the administrative practices differ through the extent of the response of those managements to the environmental changes in order to achieve the organizational success.

The organizations inability to read the environment's indexes and variables appropriately exposes them to difficulties that make the organization unable to achieve the goals with the needed effectiveness and efficacy (Danneels \& Sethi, 2011). 
Organizations differ in their perceptions and awareness about the importance of the environmental changes and its effect on the organizations and in the actual orientations to follow up those changes and comprehend them, because the environmental change rhythm is not constant for all sectors and organizations, some of the environments characterized by Deep and accelerating changes, others characterized by less speed and depth changes.

We see that the organizations that are aware of the environment importance and searching in depth about the movement of its variables or to know the occurring interactions between its elements through performing the environmental screening and going beyond the organizational boundaries, the possibilities of success of this kind of organizations will be high, and improving the administrative decision making in these organizations and making them able to avoid many of the challenges and difficulties they are encountering (Lichtenthaler, 2009).

Since successful organizations take into account the environmental changes and investigate and analyze the external environment that reflects the level of the environmental changes that was called by Mason the "Environmental Turbulence" (Mason, 2003), and since the environmental turbulence is considered as a driving variable and its screening and monitoring plays an important role in achieving high levels of financial and operational organizational performance;

Current study seeks to illustrate the effect of environmental turbulence on the organization's non-financial performance in firms of mobile telecommunications sector locating in Jordan.

\section{Literature Review}

\subsection{Environmental Turbulence}

In the organization theory literature as well as in the strategic management, turbulence is identified by two trends: The first shows that the ET represents a function for complexity in the environment seen in its dynamism forms and the environmental uncertainty.

The second trend focuses on the environment dynamism dimension including the speed and the unexpected changes (technological, clients, competitors, governmental legislations and the new products) in the organizational environment (Chen, Neubaum, Reilly, \& Lynn, 2014).

MacCormack and Verganti (2003) described the ET as an anatomical description of the responding process to the environmental changes in a flexible form, while Calantone, Garcia, and Dröge (2003) showed that ET is the uncertainty state residing in the environment and the threats/risks that it is possible to be encountered by the businesses organization.

Pavlou and El Sawy (2006) stressed that ET represents a common scale for change and prediction in the environment in which the works organization operates. In the same context, Johanesson and Palona (2010) saw that ET reflects the presence of high levels of change leading to uncertainty and inability to predict the events evolving around the organization

In other context, Azadegana, Patel, Zangoueinezhad, and Lindermand (2013) mentioned that ET includes three basic elements: environmental dynamism, environmental complexity, and environmental prediction. The Researchers showed that the environmental dynamism represents the power change degree rapidly in the public and private works environments.

Akgün, Keskin, and Byrne (2008) indicated that environmental dynamism is a rooted condition in the environment which means that there is dynamism and perpetual change in the businesses environment and the difference is in the amount and the degree of the dynamism and the change between the different organizations and the environment. Regarding complexity, Cannon and John (2007) saw that organizations are complex adaptive systems and these organizations collect the information about the surrounding environment and around themselves and behavior, and use this information for adaptation and development in a common form with the environment.

From the complexity theory point of view, the organization has created a number of connections and more able to diversify its behavior which leads to adaptation. when the organization choose the managerial response to the coordinated complexity with the adaptive system specifications they select comprehending the divers and complex environment inside the organization, which means that the organization processes multiple perceptions and sometimes contradict with the environment diversity and preserves in its behavioral memory asset of responses that each response works within low level of specialty. Such organization is characterized by multiple goals inside it and affirms the importance of the connections between its parts as a system, to get rid of distribution or the dispute resulting from adopting many objectives. 
In the current study the researcher depended in determining ET variables on (Buganza, Dell'Era, \& Verganti, 2009) and (Tsai \& Yang, 2014) including market turbulence, technological turbulence, and competitive intensity.

\subsubsection{Market Turbulence}

Slatter and Narver (1994) saw that market turbulence results from the change in the client's composition and preferences, in addition to the development in the marketing and promotion methods and ways. While Hult, Hurley, and Knight (2004) claimed that market turbulence reflects the rapid change in the buyer's preferences and their wide needs, and the change in the buyers by the entrance of new segment of purchasers to the market.

In the same context, Wang, Lo, and Yang (2004) showed that the environmental work dynamism and the continuous changes require from the organization to know the clients future needs and expectations, which requires from the organization to know the change average in the competing organizations and the environmental uncertainty in the market in which it operates.

Santos-Vijande and Álvarez-González (2007) showed that the effect of market turbulences is clear through their effect on the organizations processes, the economic recession or the economic depression affects the organization productivity, because the productivity decrease negatively reflects on the profits. In addition, the decrease in the organizations profits means that it might be unable to employ the employees and its need for lawns increases and the ability to process the capital or expansion reduces.

On the other hand, this position may push the reduction in waste of the available resources and using it optimally, and the presence in the business market for the best. Within the recession the individuals will be satisfied with what they have of long lasting goods and direct their efforts to preserve it.

\subsubsection{Technological Turbulence}

Technological turbulence indicates to the technological changes in specific sector over time, which have a great impact on creating great marketing opportunities, and reflects the mangers perceptions about the technological changes and developments in their work field (Varela \& Delrio, 2003). The effect of the technological turbulences comes through the development in the works and affects the special demand for the introduced products or services from the organization positively or negatively, this effect expands to the operational processes in the production and on the used raw material, also affects the opportunities and threats the organization is exposing to (Hall \& Rosson, 2006).

Cadogan, Cui, and Kwok Yeung Li (2003) implied that technological turbulence leads to change in the production processes, because when introducing products with new technology this will lead to the use of all/or some of the advanced and modern production methods. When a technological improvement appears suddenly in a specific product without the ability to follow the new improvement by other industrial organizations, it is for sure that these organization's products will decline (Hagel \& Brown, 2001).

The modern technology does not only grant the product or the service the competitive advantage, but also grant the new product or service the competitive marketing advantage, because any development or improvement in the technology leads in the medium or the long term to the reduction in the costs of the production elements and improving the production methods and systems, so processing the ability to compete on price also (Chandy, Prabhu, \& Antia, 2003).

One of the conditions to the success of any strategy regardless of the size and the power of the organization is the ability of the strategy makers and the administrative leaders to predict technology and discovering the future variables, and asking the following question continuously: to what extent the used current technology is able to preserve its position in the market against the competitors? This question must be in the frame of the continuous search for the technological development and improvement of the organization's products and services, because the technological prediction helps in predicting the probability degree of evolving a new technology in a specific industry and predicting the direct and indirect effect of this technology on the society and the businesses organizations generally (Wang \& Yang, 2004).

\subsubsection{Competitive Intensity}

Barnett (1997) determines competition intensity at the organizations level as the effect made by specific organizations on survival opportunity of other organizations working in the same field. Grewal and Tansuhaj (2001) demonstrated that competition intensity indicates to the degree that the organizations interface the competition against other organizations working in the same field. The competition will be intense when the competitor 
introduces a good that considers a complete alternative to a similar good that leads to prices war between the competitors and an increase in the advertising costs.

The absence of an organization that controls the industry means the absence of the one who imposes specific levels for the competition, also means a slow and decrease in the market growth average, an increase in the fixed costs and the inability to cover it, then resorting to increase the demand by reducing the prices. As a result, the consequences of these conditions are the increase and intensity of the competition degree.

Competitive intensity in the industry represents the power's center and axis that contributes to determining the industry attractiveness, and among the factors affecting the determination of the competition intensity is the industry growth, the fixed cost portion to the total value added to the activity, and the extent of depth in product differentiation, and finally the balance and centralization between the competitors (Jermias, 2008). Thus, if an industry characterized by a high growth and fixed costs relatively low, and a wide extent of the product differentiation possibility, and a high degree of centralization, then the importance is the available of greater profitability opportunities for most of the participants in the industry and vice versa (Cui, Griffith, \& Cavusgil, 2005).

Researcher of current study realizes that previous studies differ and divert in dealing with ET;

For example, AL- Nuiami, Idris, AL-Ferokh, and Abu Joma (2014) aimed in their study to examine the Moderator Effect of Entrepreneurial Orientation on the relationship between Environmental Turbulence and Innovation Performance in five-star hotels in Jordan. The results show that Environmental Turbulence (Environmental Dynamism, Environmental Complexity and Environmental Predictability) has a significant positive effect on Innovation Performance. While Stonebraker and Liao (2004), with their study under title "Environmental Turbulence', Strategic orientation Modeling Supply Chain Management", reached that there is a direct effect of both the environmental turbulence and the strategic orientation on supply chain integration.

In study of (Auh \& Mengue, 2005), the researchers aimed to show the effect of the top management functional diversity on strategic orientation and the moderating role of the environmental turbulence. While, Johnston, Gilmore, and Carson (2008) discussed how to deal within the environmental uncertainty and clarify the value from the scenario planning in the small to medium-sized establishments operating in the American local environment. However, Revilla, Prieto, and Prado (2010) discussed the knowledge strategy relationship with the environmental dynamism and complexity in the product development process.

UssahawaitIchakit (2011) tested the effect of the organization antecedence on the company's survival in the light of the information technology in Thailand through the modifying effect of the workers experience, and the environmental complexity. In the contrast, Calantone et al. (2003) reached, in the study under title "The Effect of Environmental Turbulence on New Product Development Strategy planning", that the environmental turbulence with its elements affects the new product development strategy planning in four different industries in the united states of America.

\subsection{Organizational Performance}

Performance is defined as the outcomes that the organization seeks to achieve on the long term (Morgan, Vorhies, \& Mason, 2009). In the context of (Hussein, Mohamad, Noordin, \& Ishak, 2014) study, organizational performance refers to the outcomes of various organizational processes which occur in the course of its daily operations.

Organizational performance has not been frequently defined and has been used differently according to the context, as well as being difficult to define and measure (Hussein, et al, 2014). Agarwal, Krishna Erramilli, \& Dev (2003) saw that performance represents multidimensional perspective that includes Judgmental performance indicators, such as customer service and loyalty, and the objective performance indicators such as return on investment. Despite the many efforts by the researchers, it was realized that the judgmental performance indicators are important to achieve profitability on the long term, because the objective performance indicators work to connect the Judgmental performance indicators with profitability (Heskett, Jones, Loveman, Sasser, \& Schlesinger, 1994).

Venkatraman and Ramanujam (1986) determined businesses performance field as the financial field; they placed indicators and measures for each field for the performance to be reflected within it. The financial performance is common between the writers, the researchers and the managers, whether within the applied and theoretical studies in the performance measuring process or within the practical reality in different business organizations.

Some authors go beyond this in assuring the importance of the financial performance to a limit that considers it as the organization's most important goal. Within this orientation, Hunt and Morgan (1995) expressed that importance, 
by stating that superior financial performance is considered the organization's basic goal, and the secondary goals can be achieved tacitly through achieving the high financial performance, and within the strategic perspective of the financial performance. This logic was supported by Waddok and Graves (1997); they indicated that high financial performance enables the organization to reach the needed financial resources to seize the different investment opportunities and helps to fulfill the stakeholders needs and rights and achieving their goals.

On the Contrary, Holbech (2005) believes that if a manager is interested in the total and comprehensive performance in the organization he will be more inclined to create the equilibrium between the financial and the operational interests. According to Mat and Smith (2014), the use of traditional performance measurement alone is not enough to measure performance for organizations operating in highly competitive and advanced technology environment. Further, they emphasized that organizational performance tends to be dependent upon the existence of fit between the use of organizational systems and the situational factors.

More so, Sarwoko, Armanu, and Hadiwidjojo (2013) showed that both quantitative indicators (e.g., return on investment, profit and sales volume) and qualitative indicators (e.g., knowledge, business experience) when used separately have limitations. That's why Agbim, Oriarewo, and Zever (2014) stated that the use of financial and nonfinancial methods gives better result, and it is important to entrepreneurs.

A framework was introduced to measure the operational and the financial performance through what is known as "balanced scorecard". Kaplan and Norton (1996) described this card and how it includes the financial measures that disclose the performance results, and that this card enhances those financial measures and indexes with operational measures that focus around the clients, the internal processes, and innovation and development activities in the organization. By this, the organization's future performance will be enhanced.

The Balanced Scorecard with its four perspectives (financial, customer, learning and growth, internal processes) was used by Sajedinejad and Beigzadehl (2014) and mentioned that this new performance evaluation system designed to conform to the new environmental conditions.

Dan, Liu, Hsu, and Yu (2014) in their research on small and medium family firms in Eastern culture, proposed other view for the managers when using it as a tool to help them accomplish better levels of performance in small and medium family firms, in the whole of financial measure (profitability), and non-financial measure (survival and group cohesion).

Organizational performance is a multifaceted concept. For example, Employee job analysis can be a powerful tool to enhance organizational performance (Suthar, Chakravarthi, \& Pradhan, 2014). Within the HRM literature, Dyer and Reeves (1995) use four dimensions to describe indicators of organizational performance: human resource outcomes, organizational outcomes, financial or accounting outcomes and stock-market performance indicators.

Hussein et al. (2014) propose in their paper that learning organization culture have direct effects on organizational performance and organizational innovativeness, potentially leading to long-term organizational success. In other context, Agbim et al. (2014) asserted that resources are by themselves insufficient for obtaining a sustained competitive advantage and a high performance as well. This is possible only if the firms are able to transform resources into capabilities, and consequently into positive performance. While according to openness and performance, increasing degrees of openness will stimulate innovative activities, creation of new ideas, and ultimately higher performance (Knudsen \& Mortensen, 2011).

Agbim et al. (2014) mentioned that there are a range of factors that have been associated with both successful and poor performance among small enterprises and in particular MEs. For example, Rankhumise and Rugimbana (2010) found that funding, crime and government regulations affect MEs performance in general.

Oghojafor, Dakare, and Sulaimon (2011) found that environmental scanning was significantly related to the success of the firm's performance. Pandiyan Kaliani Sundram, Razak Ibrahim, and Chandran Govindaraju (2011) reached in their study that the application of the supply chain management have positive effect on supply chain performance, and both the vision and the objectives of SC management dimensions are the most influencing than the rest of the others.

\subsection{Relationship between Environmental Turbulence and Performance}

Harrington, Lemark, Reed, and Kendall (2004) reached in their study that there is an effect of the environment dynamic on strategy formulation and the performance, using a Study sample consisted of some American companies working in the industrial field. But in study of Kuivalainen, Sundqvist, Puumalainen, and Cadogan (2004), it aimed 
to show the relationship between the environmental turbulence and international performance in knowledge intensive and non-knowledge intensive small firms operating in international markets.

The environmental determinants (environmental dynamism, hostility, and uncertainty) enhances the relationship between the entrepreneurial orientation and the export performance of the small and medium-sized firms exporting the food materials (Jalali, 2012). At the end he emphasized that innovativeness help SMEs to deal with the turbulent environmental condition and improve its export performance.

However, the environmental uncertainty affects the relation between the businesses strategy and the performance in the small and medium-sized firms in Turkey, China and the United States, according to Parnell, Lester, Long, and Köseoglu (2012).The environmental uncertainty enables the firms of interest in the competitive capabilities in enhancing the long term performance of the food industries sector (Hosseini \& Sheikhi, 2012).

Based on Agbim et al. (2014), it is pertinent to state that for business enterprises to enhance their entrepreneurial performance through business environmental scanning, they need to maintain a steady degree of interest and frequency in the scanning of their business environment.

There is an argue that the role of Absorptive Capacity on the Entrepreneurial orientation -performance relationship should be strongest in turbulent markets based on the assumption that Absorptive Capacity are most valuable in dynamic environments (Zahra, Sapienza, \& Davidsson, 2006). Engelen and her colleagues (2014) outline theoretically that absorptive capacity, helps a firm deploy its Entrepreneurial orientation in order to improve its performance, especially if the firm operates in a turbulent market (Engelena, Kube, Schmidt, \& Flatten, 2014).

In this regard, Escribano, Fosfuri, and Tribó (2009) found that environmental turbulence enhances the moderating role of absorptive capacity on the relationship between external knowledge search and firm's innovation performance. Furthermore, findings of Hung and Chou (2013) indicate that technological and market turbulence positively moderates the effect of external technology acquisition on firm performance. While Hung \& Chou (2013) have explored that Open innovation affects firm performance under environmental turbulence, which comprises from technological turbulence and market turbulence.

There is an argument that the higher the technological turbulence, the less effective external search breadth and the more effective external search depth in influencing firm's overall performance (Cruz-González, López-Sáez, Navas-López, \& Delgado-Verde, 2015). This argumentation seems to point that "paradoxically, the systems that help ensure organizational survival in stable environments contribute to inertia and organizational decline when the company is confronted with rapid change" (Hill \& Rothaermel, 2003).Therefore, we expect that in highly technologically dynamic environments the gains of depth, in terms of adaptation, will overcome its greater costs, leading to higher firm performance (Cruz-González et al., 2015).

Hung and Chou (2013) investigated the different moderating role of technological environmental dynamism and its effect on firm performance. Previous studies have observed that technological turbulence is positively associated with new product performance (Haung \& Tsai, 2014). However, other studies have indicated a negative performance effect of technological turbulence (Rijsdijk, Langerak, \& Hultink, 2011).

According to the competitive intensity, when an organization facing aggressive competitors introduces a new product to the market, the competitors may react to countervail the influence of the organization, thereby decreasing the possibility of new product success (Debruyne et al., 2002). Thus, competitive intensity is a barrier to new product success that may prevent the organization from achieving a higher performance (Huang \& Tsai, 2014).

Technological turbulence indirectly affects new product performance through product innovativeness, whereas competitive intensity directly affects new product performance. These findings imply that technological turbulence and competitive intensity may not serve as pure moderators (Huang \& Tsai, 2014). A study for Tsai and Hsu (2014) explained how competitive intensity plays a role in the relationship between cross-functional collaboration and new product performance. Tsai and his colleague indicated that "this study merely examines competitive intensity, but competitive intensity may interact with market turbulence and technology turbulence".

\subsection{Definitions}

Environmental Turbulence: The full uncertainty status in the environment and the risks that the business organizations might encounters (Pavlou \& El Sawy, 2006) and measured through:

Market Turbulence: The average change in the client's needs and desires over time.

Technology Turbulence: The extent of the technological changes faced by the industrial and service organizations over time. 
Competition Intensity: The degree to which the organizations encounter the competition from other organizations working in the same field.

Performance: The outcomes that the organization seeks to achieve on the long term (Morgan, et al, 2009).

Customer Satisfaction: the consumer's response to the evaluation of the perceived discrepancy between prior expectations (or some norm of performance) and the actual performance of the product as perceived after its consumption (Giese \& cote, 2002).

Market Effectiveness: is the quality of how marketers go to market with the goal of optimizing their spending to achieve good results for both the short-term and long-term, It is also related to Marketing ROI and Return on Marketing Investment (ROMI).

\section{Research Questions}

1) Is there a significant impact of environmental turbulence (technological turbulence, market turbulence, competitive intensity) on non-financial performance in firms of mobile TLC sector in Jordan?

2) Is there a significant impact of environmental turbulence (market turbulence, technological turbulence, competitive intensity) on customer satisfaction in firms of mobile TLC sector in Jordan?

3) Is there a significant impact of environmental turbulence (market turbulence, technological turbulence, and competitive intensity) on Market effectiveness in firms of Mobile TLC sector in Jordan?

\section{Research Hypotheses}

H1: The environmental turbulence (market turbulence, technological turbulence, competitive intensity) has a positive effect on Non-financial performance.

H1a: The environmental turbulence (market turbulence, technological turbulence, competitive intensity) has a positive effect on customer satisfaction.

H1b: The environmental turbulence (market turbulence, technological turbulence, competitive intensity) has a positive effect on Market effectiveness.

\section{The Proposed Structural Model}

In determining the Environmental Turbulence dimensions, the study depended on (Tsai \& Yang, 2012), (Tsai \& Yang, 2013) and (Buganza, et al., 2009).

Regarding to performance variable, it was measured according to the non-financial indicators relating to the customer (Customer Satisfaction) and the market (Market Effectiveness) depending on (Engelena et al., 2014), (Vorhies \& Morgan, 2005) and (Hogue, 2004; Kaplan \& Norton, 1996)

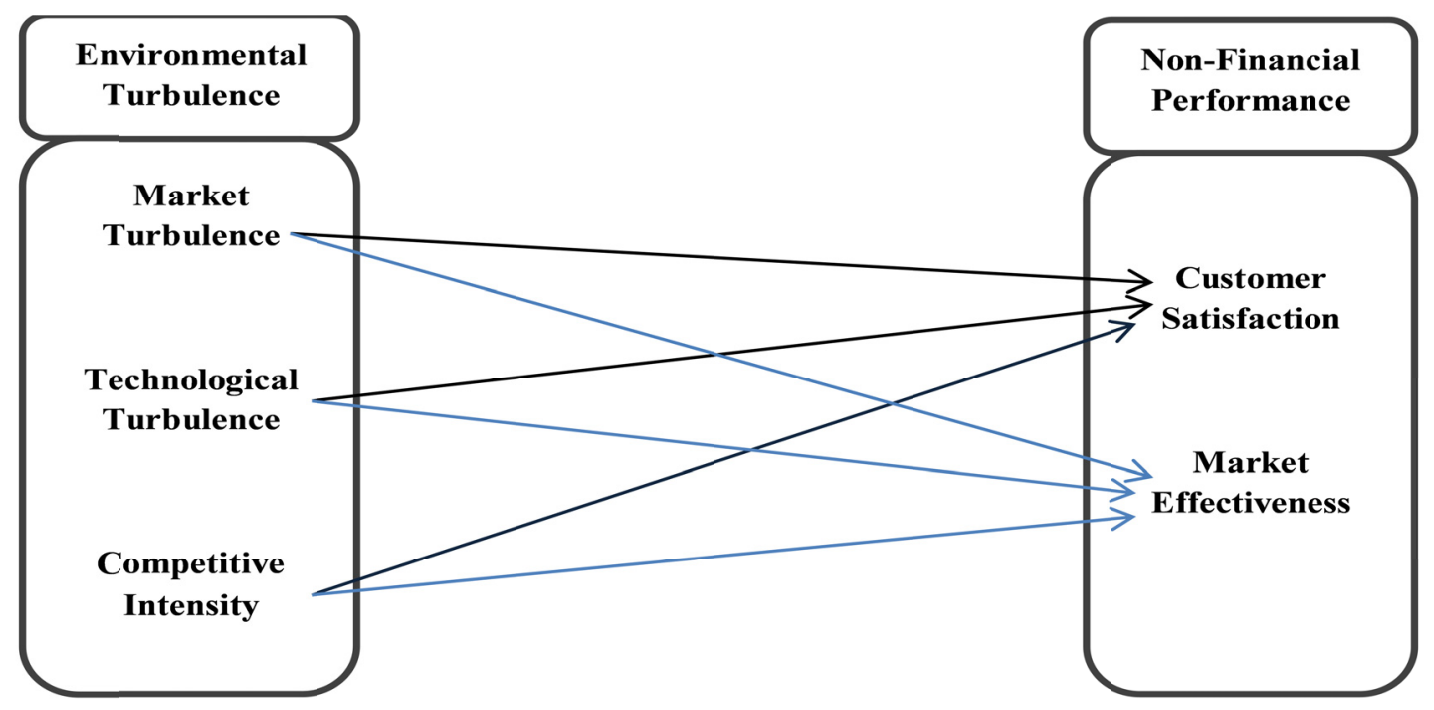

Figure 1. Proposed structural model 
Figure 1 illustrates the proposed structural model which indicated the environmental turbulence as an independent variable including three factors: Market turbulence, technological turbulence, and competitive intensity. These three factors were supposed to have impact on non-financial performance (as a dependent variable).

\section{Research Methods, Analysis and Results}

A questionnaire was used for collecting data from all employees of managers, assistant managers and heads of departments working in all firms of Mobile TLC sector in Jordan (ORANGE, UMNIAH and ZAIN Firms).

After distributing (90) questionnaires for, a total of (87) answered questionnaires were retrieved, of which (3) were invalid, Therefore, (84) answered questionnaires from respond were valid for study. The Five Likert Scale was used in the questionnaire, see Appendix (A).

Table 1. Descriptive the personal \& occupational characteristics of the study sample

\begin{tabular}{|c|c|c|c|}
\hline Variables & Categorization & Frequency & Percent \\
\hline \multirow{4}{*}{ Age } & Less than 30 Years & 8 & 10 \\
\hline & From $30-34$ Years & 46 & 55 \\
\hline & From $35-39$ Years & 18 & 21 \\
\hline & 40 Years and more & 12 & 14 \\
\hline \multirow{2}{*}{ Gender } & Male & 67 & 79.8 \\
\hline & Female & 17 & 20.2 \\
\hline \multirow{5}{*}{ Qualification } & Diploma & 2 & 2 \\
\hline & Bachelor & 50 & 60 \\
\hline & High Diploma & 7 & 8 \\
\hline & Master & 22 & 26 \\
\hline & Doctorate & 3 & 4 \\
\hline \multirow{4}{*}{ Experience } & Less than 5 Years & 14 & 17 \\
\hline & From $6-10$ Years & 32 & 38 \\
\hline & From $11-15$ Years & 21 & 25 \\
\hline & 16 Years and more & 17 & 20 \\
\hline \multirow{3}{*}{ Managerial level } & Manager & 3 & 3 \\
\hline & Subordinate & 8 & 10 \\
\hline & Head of Division & 73 & 87 \\
\hline \multicolumn{2}{|c|}{ Total } & 84 & 100 \\
\hline
\end{tabular}

Cronbach's alpha, was used to determine the internal consistency reliability of the elements comprising the five constructs as suggested by (Gregory, 2004). Reliability should be (0.60) or higher to indicate adequate convergence or internal consistency (Sekaran \& Bougie, 2010: 184).

These results are the acceptable levels as suggested by (Sekaran \& Bougie, 2010: 184). The results were shown in Table 2. 
Table 2. Reliability of questionnaires dimensions

\begin{tabular}{ccccc}
\hline No. & Variable & Dimensions & No of items & Cronbach's alpha Value \\
\hline 1 & \multicolumn{2}{c}{ Environmental Turbulence } & 15 & 0.885 \\
\hline & $(2-1)$ & Market Turbulence & 5 & 0.792 \\
& $(2-2)$ & Technological Turbulence & 5 & 0.721 \\
& $(2-3)$ & Competitive Intensity & 5 & 0.724 \\
\hline 2 & \multicolumn{2}{c}{ Non-Financial Performance } & 8 & 0.792 \\
\hline & $(2-1)$ & Customer Satisfaction & 4 & 0.637 \\
& $(2-2)$ & Market effectiveness & 4 & 0.677 \\
\hline
\end{tabular}

\subsection{Study Variables Description}

The descriptive analysis of environmental turbulence dimensions presented in table (3) that demonstrates the general mean scores (4.195) for environmental turbulence which indicate high degree of environmental turbulence in firms of Mobile telecommunications sector at Jordan characterized it. On the other hand, every environmental turbulence dimension notes that the mean scores ranged between (4.097) for Competitive Intensity dimension and (4.252) for Technological Turbulence dimension which indicate high degree.

Table 3. Descriptive statistics of environmental turbulence dimensions

\begin{tabular}{|c|c|c|c|}
\hline No. & Environmental Turbulence Dimensions & Mean & St.D \\
\hline 1 & customers' preferences in the telecommunications sector change quite a bit overtime & 4.297 & 0.616 \\
\hline 2 & $\begin{array}{l}\text { Our customers in the telecommunications sector tend to look for new products all the } \\
\text { time }\end{array}$ & 4.154 & 0.702 \\
\hline 3 & $\begin{array}{l}\text { Our customers are very price-sensitive, but on other occasions, price is relatively } \\
\text { unimportant }\end{array}$ & 4.095 & 0.704 \\
\hline 4 & $\begin{array}{l}\text { We are witnessing demand for our products and services from customers who did not } \\
\text { deal with us previously. }\end{array}$ & 4.178 & 0.584 \\
\hline 5 & $\begin{array}{l}\text { The needs of the new customers differ from the needs required by our current } \\
\text { customers }\end{array}$ & 4.452 & 0.589 \\
\hline \multicolumn{2}{|r|}{ Market Turbulence Mean and Standard deviation } & 4.235 & 0.474 \\
\hline 6 & The technology in telecommunications sector is changing rapidly & 4.107 & 0.658 \\
\hline 7 & Technological changes provide big marketing opportunities in our sector & 4.381 & 0.638 \\
\hline 8 & $\begin{array}{l}\text { A large number of new product ideas have been made possible through technological } \\
\text { innovations }\end{array}$ & 4.357 & 0.613 \\
\hline 9 & $\begin{array}{l}\text { telecommunications work within the competition requires technological } \\
\text { developments and adoption it }\end{array}$ & 4.214 & 0.539 \\
\hline 10 & It is difficult to predict the technological changes in telecommunications sector & 4.202 & 0.554 \\
\hline \multicolumn{2}{|r|}{ Technological Turbulence Mean and Standard deviation } & 4.252 & 0.414 \\
\hline 11 & Competition in the telecommunications sector is very intense & 4.250 & 0.637 \\
\hline 12 & There are many intense "promotion wars" in telecommunications sector. & 3.797 & 0.954 \\
\hline 13 & $\begin{array}{l}\text { For anything that one competitor can offer to the customers, others can match readily } \\
\text { and provide immediately. }\end{array}$ & 3.654 & 1.023 \\
\hline 14 & Price competition is a hallmark of telecommunications sector. & 4.404 & 0.660 \\
\hline 15 & One hears of a competitive move almost every day in telecommunications firms & 4.381 & 0.535 \\
\hline \multicolumn{2}{|r|}{ Competitive Intensity Mean and Standard deviation } & 4.097 & 0.541 \\
\hline & Environmental Turbulence Mean and Standard deviation & 4.195 & 0.421 \\
\hline
\end{tabular}


As shown in Table 4, the general mean scores (4.215) which indicate high level of Non- financial Performance in firms of mobile telecommunications sector at Jordan characterized it.

Table 4. Descriptive statistics of non- financial performance dimensions

\begin{tabular}{rlrl}
\hline No. & Non- financial Performance Dimensions & Mean & St.D \\
\hline 16 & Overall customer satisfaction & 3.773 & 0.840 \\
17 & Delivering value to your customers & 4.250 & 0.578 \\
18 & Delivering what your customers want & 4.226 & 0.700 \\
\hline 19 & Retaining valued customers & 4.261 & 0.623 \\
\hline & Customer Satisfaction Mean and Standard deviation & 4.128 & 0.479 \\
\hline 20 & Market share growth relative to competitors & 4.297 & 0.576 \\
\hline 21 & Growth in sales revenue & 4.583 & 0.519 \\
\hline 22 & Acquiring new customers & 4.226 & 0.664 \\
\hline 23 & Increasing sales to existing customers & 4.107 & 0.821 \\
\hline & Market effectiveness Mean and Standard deviation & 4.303 & 0.467 \\
\hline & Non- financial Performance Mean and Standard deviation & 4.215 & 0.430 \\
\hline
\end{tabular}

\subsection{Testing Hypotheses}

H1: The environmental turbulence (market turbulence, technological turbulence, competitive intensity) has a positive effect on Non-financial performance.

Through using multiple regressions analysis, significant positive effects of environmental turbulence on Non-financial performance.

Table 5 illustrates that environmental turbulence (technological turbulence and competitive intensity) has a significant positive effects on Non-financial performance. The regression model achieve a high degree of fit, as reflected by "R"

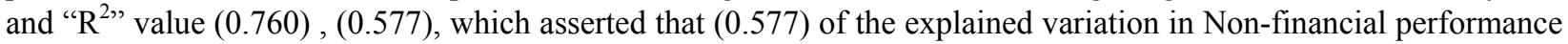
can be accounted for environmental turbulence (technological turbulence and competitive intensity). On the other hand, the Table (5) for the executive data set indicated the slope value of $(0.303)$ and $(0.356)$ for the regression line. This suggested that for a one unit increase in environmental turbulence (technological turbulence and competitive intensity) the respective organization can significantly predict a (0.303) and (0.356) increase in Non-financial performance. As well as Table 5 shows that the analysis of variance of the fitted regression equation is significant with $\mathrm{F}$ value of (36.423). This is an indication that the model is a good one. Since the $p$ value is less than (0.05), it shows a statistically significant relationship between the variables at (0.95) confidence level. The results also indicate that environmental turbulence (technological turbulence and competitive intensity) have significant positively effect on Non-financial performance with a coefficient of (0.303) for technological turbulence and (0.356) for competitive intensity. Therefore, the hypothesis of a significant positive effect fails to be rejected. Thus, environmental turbulence (technological turbulence and competitive intensity) has a significant positive effect on Non-financial performance. This further supported the main study hypothesis.

Table 5. Summary of multiple regression results - effects of environmental turbulence on non-financial performance

\begin{tabular}{|c|c|c|c|c|c|c|c|c|}
\hline \multicolumn{2}{|c|}{ Model Summary } & \multicolumn{3}{|c|}{$A N O V A$} & \multicolumn{4}{|c|}{ Coefficients } \\
\hline $\boldsymbol{R}$ & $R^{2}$ & F Calculate & $D F$ & Sig* & $\boldsymbol{\beta}$ & & T Calculate & Sig* \\
\hline \multirow{3}{*}{0.760} & \multirow{3}{*}{0.577} & \multirow{3}{*}{36.423} & 3 & \multirow{3}{*}{0.000} & Market turbulence & 0.199 & 1.687 & 0.096 \\
\hline & & & 80 & & Technological turbulence & 0.303 & 2.610 & 0.011 \\
\hline & & & 83 & & Competitive intensity & 0.356 & 3.599 & 0.001 \\
\hline
\end{tabular}


H1a: The environmental turbulence (market turbulence, technological turbulence, competitive intensity) has a positive effect on customer satisfaction

Through using multiple regressions analysis, significant positive effects of environmental turbulence on Customer Satisfaction.

Table 6 illustrates that environmental turbulence (Market turbulence and competitive intensity) has a significant positive effects on Customer Satisfaction. The regression model achieve a high degree of fit, as reflected by "R" and

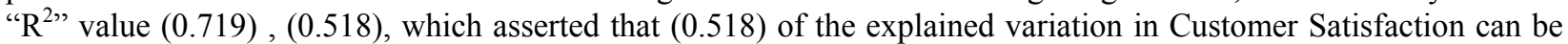
accounted for environmental turbulence (Market turbulence and Competitive intensity). On the other hand, the Table (6) for the executive data set indicated the slope value of $(0.304)$ and (0.397) for the regression line. This suggested that for a one unit increase in environmental turbulence (Market turbulence and Competitive intensity) the respective organization can significantly predict a (0.304) and (0.397) increase in Customer Satisfaction. As well as Table (6) shows that the analysis of variance of the fitted regression equation is significant with $\mathrm{F}$ value of (28.620). This is an indication that the model is a good one. Since the $\mathrm{p}$ value is less than (0.05), it shows a statistically significant relationship between the variables at $(0.95)$ confidence level. The results also indicate that environmental turbulence (Market turbulence and Competitive intensity) significant positively effects on Customer Satisfaction with a coefficient of (0.304) for Market turbulence and (0.397) for competitive intensity. Therefore, the hypothesis of a significant positive affect fails to be rejected. Thus, environmental turbulence (Market turbulence and Competitive intensity) has a significant positive effect on Customer Satisfaction. This further supported the first sub study hypothesis.

Table 6. Summary of multiple regression results - effects of environmental turbulence on customer satisfaction

\begin{tabular}{|c|c|c|c|c|c|c|c|c|}
\hline \multicolumn{2}{|c|}{ Model Summary } & \multicolumn{3}{|c|}{ ANOVA } & \multicolumn{4}{|c|}{ Coefficients } \\
\hline $\boldsymbol{R}$ & $R^{2}$ & F Calculate & $D F$ & Sig* & $\beta$ & & T Calculate & Sig* \\
\hline \multirow{3}{*}{0.719} & \multirow{3}{*}{0.518} & \multirow{3}{*}{28.620} & 3 & \multirow{3}{*}{0.000} & Market turbulence & 0.304 & 2.410 & 0.018 \\
\hline & & & 80 & & Technological turbulence & 0.105 & 0.845 & 0.400 \\
\hline & & & 83 & & Competitive intensity & 0.397 & 3.753 & 0.000 \\
\hline
\end{tabular}

H1b: The environmental turbulence (market turbulence, technological turbulence, competitive intensity) has a positive effect on Market effectiveness.

Through using multiple regressions analysis, significant positive effects of environmental turbulence on Market effectiveness.

Table 7 illustrates that environmental turbulence (Technological turbulence and competitive intensity) has a significant positive effects on Market effectiveness. The regression model achieve a high degree of fit, as reflected by " $R$ " and " $R$ ", value $(0.681),(0.463)$, which asserted that $(0.463)$ of the explained variation in Market effectiveness can be accounted for environmental turbulence (Technological turbulence and Competitive intensity). On the other hand, the Table 7 for the executive data set indicated the slope value of $(0.450)$ and (0.249) for the regression line. This suggested that for a one unit increase in environmental turbulence (Technological turbulence and Competitive intensity) the respective organization can significantly predict a (0.450) and (0.249) increase in Market effectiveness. As well as Table 7 shows that the analysis of variance of the fitted regression equation is significant with $\mathrm{F}$ value of (23.010). This is an indication that the model is a good one. Since the $\mathrm{p}$ value is less than (0.05), it shows a statistically significant relationship between the variables at (0.95) confidence level. The results also indicate that environmental turbulence (Technological turbulence and Competitive intensity) significant positively effects on Market effectiveness with a coefficient of (0.450) for Technological turbulence and (0.249) for competitive intensity. Therefore, the hypothesis of a significant positive effect fails to be rejected. Thus, environmental turbulence (Technological turbulence and Competitive intensity) has a significant positive effect on Market effectiveness. This further supported the second sub study hypothesis. 
Table 7. Summary of multiple regression results - effects of environmental turbulence on market effectiveness

\begin{tabular}{|c|c|c|c|c|c|c|c|c|}
\hline \multicolumn{2}{|c|}{ Model Summary } & \multicolumn{3}{|c|}{ ANOVA } & \multicolumn{4}{|c|}{ Coefficients } \\
\hline $\boldsymbol{R}$ & $R^{2}$ & F Calculate & $D F$ & Sig* & $\beta$ & & T Calculate & Sig* \\
\hline \multirow{3}{*}{0.681} & \multirow{3}{*}{0.463} & \multirow{3}{*}{23.010} & 3 & \multirow{3}{*}{0.000} & Market turbulence & 0.055 & 0.413 & 0.681 \\
\hline & & & 80 & & Technological turbulence & 0.450 & 3.440 & 0.001 \\
\hline & & & 83 & & Competitive intensity & 0.249 & 2.231 & 0.029 \\
\hline
\end{tabular}

In order to achieve the study objectives in a holistic manner, the researcher using AMOS 21 to build a proposed model that illustrates the effect the environmental turbulence on Non-financial performance using a structural equation model.

The structural model tested in the present study is shown in Figure 2. This model was estimated using AMOS 21. The $X^{2}$ statistic of 10.337 is within the acceptable limit. Several goodness of fit indices of the structural model have been widely used and are presented in Table (8). The goodness of fit (GFI), comparative fit index (CFI), adjusted goodness of fit index (AGFI) and Normed fit index (NFI) are all above 0.90 suggesting a good fit between the structural model and the data. RMSEA is well below the suggested threshold value of 0.08 . All of these fit indices are acceptable, suggesting that the overall structural model provides a good fit with the data. The squared multiple correlation (SMC) values, which are similar to in regression analysis, show that this model accounts for 0.351 of the variance in Customer Satisfaction, 0.333 of the variance in Market effectiveness.

Table 8 . Fit indices of structural model

\begin{tabular}{|c|c|c|c|c|c|c|c|c|}
\hline & & & & & Estimate & S.E & C.R & $P$ \\
\hline Market turb & & $\rightarrow$ & \multicolumn{2}{|c|}{ Customer Satisfaction } & 0.308 & 0.125 & 2.455 & 0.014 \\
\hline Market turb & & $\rightarrow$ & \multicolumn{2}{|c|}{ Market effectiveness } & 0.061 & 0.129 & 0.420 & 0.674 \\
\hline $\begin{array}{l}\text { Technolo } \\
\text { turbule }\end{array}$ & & $\rightarrow$ & \multicolumn{2}{|c|}{ Customer Satisfaction } & 0.122 & 0.141 & 0.861 & 0.389 \\
\hline $\begin{array}{l}\text { Technolo } \\
\text { turbule }\end{array}$ & & $\rightarrow$ & \multicolumn{2}{|c|}{ Market effectiveness } & 0.508 & 0.145 & 3.504 & $* * *$ \\
\hline Competitive & sity & $\rightarrow$ & \multicolumn{2}{|c|}{ Customer Satisfaction } & 0.351 & 0.092 & 3.822 & $* * *$ \\
\hline Competitive & sity & $\rightarrow$ & \multicolumn{2}{|c|}{ Market effectiveness } & 0.215 & 0.095 & 2.272 & 0.023 \\
\hline \multicolumn{3}{|c|}{$X^{2}=10.337$} & \multicolumn{3}{|c|}{$\boldsymbol{D F}=4$} & \multicolumn{3}{|c|}{$\boldsymbol{P}=0.067$} \\
\hline \multirow{4}{*}{$\begin{array}{c}\text { Results of } \\
\text { goodness of } \\
\quad \text { fit }\end{array}$} & \multicolumn{3}{|c|}{ Absolute Fit Level } & \multicolumn{3}{|c|}{ Incremental Fit Level } & \multicolumn{2}{|c|}{ Parsimonious Fit Level } \\
\hline & \multicolumn{2}{|c|}{ GFI } & RMSEA & $A G F I$ & CFI & $N F I$ & $\chi^{2} / D F$ & $S M C\left(R^{2}\right)$ \\
\hline & \multirow{2}{*}{\multicolumn{2}{|c|}{0.902}} & \multirow{2}{*}{0.027} & \multirow{2}{*}{0.913} & \multirow{2}{*}{0.925} & \multirow{2}{*}{0.967} & \multirow{2}{*}{2.584} & $\mathrm{CS}=0.351$ \\
\hline & & & & & & & & $\mathrm{ME}=0.333$ \\
\hline
\end{tabular}




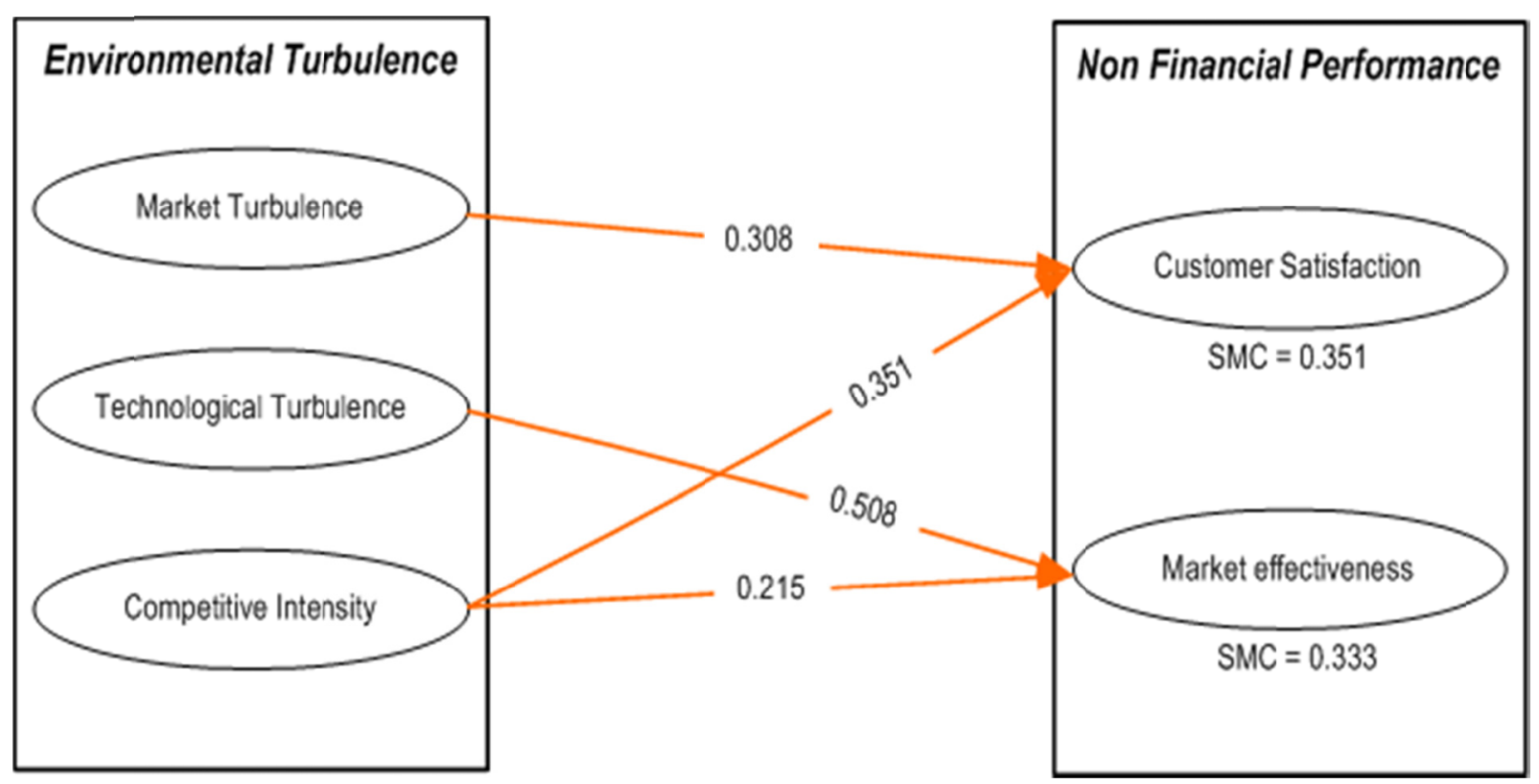

Figure 2. Structural equation model results

According to the hypotheses testing results and fit indices values, the proposed structural equation model should be as follows in Figure 2, showing the relationships between the study variables.

\section{The Study Contributions}

The current study derives its importance from being related to the topic environmental turbulence as a driving variable for non- financial organizational performance, especially in organizations working in Mobile TLC sector in Jordan, and as a result for achieving high performance levels. Moreover, a Structural Equation Model (SEM) was constructed for analyzing this relationship.

Also, its importance stems from the lack and limited studies in the Middle East Area that addressed the concept of environmental turbulence as a whole, and precisely the relation and coherence between the two current study variables (ET and Non-financial performance) in Mobile TLC sector.

In addition, there are many different variables that were measured in the previous studies, while the current study measures the environmental turbulence through Market Turbulence, Technological Turbulence and Competitive Intensity, depending on studies of Tsai and Yang (2012), Tsai and Yang (2013) and Buganza et al. (2009).

Regarding to performance variable, it is measured according to the non-financial indicators related to the customer (Customer Satisfaction) and the market (Market Effectiveness) depending on Engelena et al. (2014), Vorhies and Morgan (2005) and Hogue (2004); Kaplan and Norton (1996).

Finally, this study derives its practical importance with the help of those in charge of the mobile TLC firms in Jordan to acquire the importance of the environmental turbulence and to take into consideration its role that plays in achieving high performance levels in mobile TLC sector in Jordan.

As a summary, the most important things that distinguish this study from the other studies can be summarized as follow:

-Regarding the abundance of related studies: the limitation and lack of previous studies in the Middle East Area that addressed the concept of environmental turbulence as a whole, and precisely the relation and coherence between the two current study variables in firms of mobile TLC sector.

- Regarding the study variables: there are many different variables that were measured in the previous studies, while the current study measures the environmental turbulence through these three dimensions: market turbulence, technological turbulence and competitive intensity, depending on studies of Tsai and Yang (2012), Tsai and Yang (2013) and Buganza et al. (2009). 
Regarding to performance variable, it is measured according to the non-financial indicators related to the customer (customer satisfaction) and the market (market effectiveness) depending on Engelena et al. (2014), Vorhies and Morgan (2005) and Hogue (2004); Kaplan and Norton (1996).

- Regarding the study goal: The previous researches trends are vary and aimed to show the importance and the mechanisms for measuring the environmental turbulence in addition to the role that the environmental turbulence plays in enhancing the organizational performance directly or as a moderator through managing other variables inside the organization.

As the literature review shows, most of the previous studies are dealing with the turbulence as a moderator or mediator in its relationship with the performance.

While this current study seeks to know the direct effect of the environmental turbulence (as an independent variable) on non-financial performance in firms of mobile TLC sector in Jordan.

So, this study derives its significance from the following scientific and practical considerations:

1. It sheds light on the environmental turbulence implications that face the organizations generally, and the Mobile TLC sector in Jordan and its importance in achieving high performance levels and its contribution in achieving the goals on the long term.

2. This study contributes to opening other researches' horizons addressing the environmental turbulence and concerning about it, especially in mobile TLC firms in Jordan.

3. Achieving the benefits to the firms of Mobile TLC sector in Jordan and to the decision makers in these firms, also to those interesting in this sector.

\section{Conclusions, Limitations and Further Research}

This article provides an empirical justification for a structural model that identifies three key dimensions of ET and two dimensions of NFP. It confirms that Technological Turbulence and Competitive Intensity constructs of ET enhance the firm's Non-Financial Performance, the market turbulence and competitive intensity constructs of ET enhances the Customer Satisfaction, and the technological turbulence and competitive intensity constructs of ET enhances the Market Effectiveness.

In view of this result, we can conclude that the confirmation and fit of the overall structural model was important because it provides empirical evidence that ET do really has impact on NFP in Mobile TLC Firms in Jordan.

Some difficulties were faced in collecting back the questionnaires because of the weak responses of the questionnaire respondents. And if we can use more measures for ET and NFP drawn from the software or consultant companies instead of self-reporting by the firms, the results will be more convincing.

Furthermore, while the sample consisted of Jordanian Mobile TLC firms, it might be better to collect data from Mobile TLC firms of other countries in the Middle East area, such as Egypt, United Arab Emirates, Iran and Turkey.

As the concept of ET is complex and involves a network of organizations all are exposed to technological changing, changes in clients' needs and high level of competition, its entire domain cannot be covered in just one study. Future research can expand the domain of ET by considering other constructs such as environmental dynamism, environmental complexity and predictability which were not included in this study.

Additionally, this study adopted only two Non-financial dimensions for performance and did not address the financial ones. Future research have opportunity to include additional Non-financial performance measures, such as new product development; Research and development (R\&D); cost control; Personnel development; Workplace relations; and Employee health and safety. And the financial measures such as the operating income; return on Sales; Return on investment; Cash flow from operations; and Business unit profitability.

It is a fact that turbulence has different effect on public authorities and private companies. However, there has not been any extensive research yet about the effects of the differences on their performance and this can be investigated in future studies, in addition to the impact of ET on International Performance of high tech firms working in international markets.

Thus, this study contributes to opening other researches' horizons addressing the environmental turbulence and concerning about it, especially in firms of mobile TLC sector. 


\section{References}

Agarwal, S., Krishna Erramilli, M., \& Dev, C. S. (2003). Market orientation and performance in service firms: role of innovation. Journal of services marketing, 17(1), 68-82.

Agbim, K. C., Oriarewo, G. O., \& Zever, T. A. (2014). Moderating Effects of Individual Entrepreneur and Enterprise Characteristics on the Relationship between Business Environmental Scanning Behaviour and Entrepreneurial Performance. Journal of Business Studies Quarterly, 6(1).

Akgün, A. E., Keskin, H., \& Byrne, J. (2008). The moderating role of environmental dynamism between firm emotional capability and performance. Journal of Organizational Change Management, 21(2), $230-252$.

AL- Nuiami, M., Idris, W. M. S., AL-Ferokh, F. A. M., \& Abu Joma, M. H. M. (2014). An Empirical Study of the Moderator Effect of Entrepreneurial Orientation on the Relationship between Environmental Turbulence and Innovation Performance in Five-star Hotels in Jordan. International Journal of Business Administration, 5(2), 111-125.

Auh, S., \& Menguc, B. (2005). The influence of top management team functional diversity on strategic orientations: The moderating role of environmental turbulence and inter-functional coordination. International Journal of Research in Marketing, 22, 333-350.

Azadegan, A., Patel, P. C., Zangoueinezhad, A., \& Linderman, K. (2013). The effect of environmental complexity and environmental dynamism on lean practices. Journal of Operations Management, 31(4), 193-212.

Barnett, W. P. (1997). The dynamics of competitive intensity. Administrative Science Quarterly, 42, $128-160$.

Buganza, T., Dell'Era, C., \& Verganti, R. (2009). Exploring the Relationships Between Product Development and Environmental Turbulence: The Case of Mobile TLC Services. Journal of Product Innovation Management, 26(3), 308-321.

Cadogan, J. W., Cui, C. C., \& Kwok Yeung Li, E. (2003). Export market-oriented behavior and export performance: The moderating roles of competitive intensity and technological turbulence. International marketing review, 20(5), 493-513.

Calantone, R., Garcia, R., \& Dröge, C. (2003). The effects of environmental turbulence on new product development strategy planning. Journal of Product Innovation Management, 20(2), 90-103.

Cannon, A. R., \& John, C. H. S. (2007). Measuring Environmental Complexity A Theoretical and Empirical Assessment. Organizational Research Methods, 10(2), 296-321.

Chandy, R. K., Prabhu, J. C., \& Antia, K. D. (2003). What will the future bring? Dominance, technology expectations, and radical innovation. Journal of Marketing, 67(3), 1-18.

Chen, J., Neubaum, D. O., Reilly, R. R., \& Lynn, G. S. (2015). The relationship between team autonomy and new product development performance under different levels of technological turbulence. Journal of Operations Management, 33, 83-96.

Cruz-González, J., López-Sáez, P., Navas-López, J. E., \& Delgado-Verde, M. (2015). Open search strategies and firm performance: The different moderating role of technological environmental dynamism. Technovation, 35, $32-45$.

Cui, A. S., Griffith, D. A., \& Cavusgil, S. T. (2005). The influence of competitive intensity and market dynamism on knowledge management capabilities of multinational corporation subsidiaries. Journal of International Marketing, 13(3), 32-53.

Dan, N. H., Liu, Y., Hsu, P. F., \& Yu, S. H. (2014). An Empirical Study of the Organizational Culture, Leadership and Firm Performance in a Vietnam Family Business. International Journal of Organizational Innovation (Online), 6(4), 109.

Debruyne, M., Moenaertb, R., Griffinc, A., Hartd, S., Hultinke, E. J., \& Robben, H. (2002). The impact of new product launch strategies on competitive reaction in industrial markets. Journal of Product Innovation Management, 19(2), 159-170.

Dyer, L., \& Reeves, T. (1995). Human resource strategies and firm performance: what do we know and where do we need to go?. International Journal of human resource management, 6(3), 656-670.

Engelen, A., Kube, H., Schmidt, S., \& Flatten, T. C. (2014). Entrepreneurial orientation in turbulent environments: The moderating role of absorptive capacity. Research Policy, 43(8), 1353-1369. 
Escribano, A., Fosfuri, A., \& Tribó, J. A. (2009). Managing external knowledge flows: The moderating role of absorptive capacity. Research policy, 38(1), 96-105.

Giese, J. L., \& Cote, J. A. (2000). Defining consumer satisfaction. Academy of marketing science review, $2000,1$.

Gregory, R. J. (2004). Psychological testing: History, principles, and applications. Allyn \& Bacon.

Grewal, R., \& Tansuhaj, P. (2001). Building organizational capabilities for managing economic crisis: The role of market orientation and strategic flexibility. Journal of marketing, 65(2), 67-80.

Hagel, J., \& Brown, J. (2001). Your next IT strategy. Harvard Business Review, 79, 105-113.

Hall, J., \& Rosson, P. (2006). The impact of technological turbulence on entrepreneurial behavior, social norms and ethics: Three internet-based cases. Journal of Business Ethics, 64(3), 231-248.

Harrington, R. J., Lemak, D. J., Reed, R., \& Kendall, K. W. (2004). A question of fit: The links among environment, strategy formulation, and performance. Journal of Business and Management, 10(1), 15-38.

Heskett, J. L., Jones, T. O., Loveman, G. W., Sasser Jr, W. E., \& Schlesinger, L. A. (1994). Putting the service-profit chain to work. Harvard business review, 72(2), 164-174.

Hill, C. W., \& Rothaermel, F. T. (2003). The performance of incumbent firms in the face of radical technological innovation. Academy of Management Review, 28(2), 257-274.

Hoque, Z. (2004). A contingency model of the association between strategy, environmental uncertainty and performance measurement: impact on organizational performance. International Business Review, 13(4), 485-502.

Holbeche, L. (2005). The high performance organization: creating dynamic stability and sustainable success. Routledge.

Hosseini, S. M., \& Sheikhi, N. (2012). An empirical examination of competitive capability's contribution toward firm performance: Moderating role of perceived environmental uncertainty. International Business Research, 5(5), 116-131.

Huang, C. T., \& Tsai, K. H. (2014). Synergy, environmental context, and new product performance: a review based on manufacturing firms. Industrial Marketing Management, 43(8), 1407-1419.

Hult, G. T. M., Hurley, R. F., \& Knight, G. A. (2004). Innovativeness: Its antecedents and impact on business performance. Industrial marketing management, 33(5), 429-438.

Hung, K. P., \& Chou, C. (2013). The impact of open innovation on firm performance: The moderating effects of internal R\&D and environmental turbulence. Technovation, 33(10), 368-380.

Hunt, S. D., \& Morgan, R. M. (1995). The comparative advantage theory of competition. Journal of Marketing, $59(2), 1-15$.

Hussein, N., Mohamad, A., Noordin, F., \& Ishak, N. A. (2014). Learning organization and its effect on organizational performance and organizational innovativeness: A proposed framework for Malaysian Public Institutions of Higher Education. Procedia-Social and Behavioral Sciences, 130, 299-304.

Jalali, S. H. (2012). Environmental determinants, entrepreneurial orientation and export performance: Empirical evidence from Iran. Serbian Journal of Management, 7(2), 245-255.

Jermias, J. (2008). The relative influence of competitive intensity and business strategy on the relationship between financial leverage and performance. The British Accounting Review, 40(1), 71-86.

Johannesson, J., \& Palona, I. (2010). Environmental turbulence and the success of a firm's intelligence strategy: development of research instruments. International Journal of Management, 27(3), 448-458.

Johnston, M., Gilmore, A., \& Carson, D. (2008). Dealing with environmental uncertainty: The value of scenario planning for small to medium-sized enterprises (SMEs). European Journal of Marketing, 42(11/12), 1170-1178.

Kaplan, R. S., \& Norton, D. P. (1996). Linking the balanced scorecard to strategy. California management review, 39(1), 53-79.

Knudsen, M. P., \& Mortensen, T. B. (2011). Some immediate-but negative-effects of openness on product development performance. Technovation, 31(1), 54-64. 
Kuivalainen, O., Sundqvist, S., Puumalainen, K., \& Cadogan, J. W. (2004). The effect of environmental turbulence and leader characteristics on international performance: are knowledge - based firms different?. Canadian Journal of Administrative Sciences/Revue Canadienne des Sciences de l'Administration, 21(1), 35-50.

MacCormack, A., \& Verganti, R. (2003). Managing the sources of uncertainty: Matching process and context in software development. Journal of Product Innovation Management, 20(3), 217-232.

Mat, T. Z. T., \& Smith, M. (2014). The impact of changes in environment and AMT on management accounting practices and organizational strategy, structure and performance. Journal of Applied Management Accounting Research, 12(1), 55.

Morgan, N. A., Vorhies, D. W., \& Mason, C. H. (2009). Market orientation, marketing capabilities, and firm performance. Strategic Management Journal, 30(8), 909-920.

Oghojafor, B. E. A., Dakare, O., \& Sulaimon, A.A. (2011). Assessing small and medium enterprises environment in Nigeria. International Journal of African Studies, 4, 22-27.

Pandiyan Kaliani Sundram, V., Razak Ibrahim, A., \& Chandran Govindaraju, V. G. R. (2011). Supply chain management practices in the electronics industry in Malaysia: Consequences for supply chain performance. Benchmarking: An International Journal, 18(6), 834-855.

Parnell, J. A., Lester, D. L., Long, Z., \& Köseoglu, M. A. (2012). How environmental uncertainty affects the link between business strategy and performance in SMEs: Evidence from China, Turkey, and the USA. Management Decision, 50(4), 546-568.

Pavlou, P. A., \& El Sawy, O. A. (2006). From IT leveraging competence to competitive advantage in turbulent environments: The case of new product development. Information Systems Research, 17(3), 198-227.

Rankhumise, E. M., \& Rugimbana, R. O. (2010). Micro enterprise owner perspectives on performance: Insights from selected municipalities in Mpumalanga province, South Africa. African Journal of Business Management, 4(16), 3500-3507.

Revilla, E., Prieto, I. M., \& Prado, B. R. (2010). Knowledge strategy: Its relationship to environmental dynamism and complexity in product development. Knowledge and process Management, 17(1), 36-47.

Rijsdijk, S. A., Langerak, F., \& Jan Hultink, E. (2011). Understanding a Two - Sided Coin: Antecedents and Consequences of a Decomposed Product Advantage*. Journal of Product Innovation Management, 28(1), $33-47$.

Sajedinejad, A., \& Beigzadeh, N. (2014, April 24-25). Providing Key Indicators for Evaluating the E-Business Context for Improving Performance of Insurance Companies in Iran. Paper presented at the 8th International Conference on e-Commerce with focus on e-Trust, Iran.

Santos-Vijande, M. L., \& Álvarez-González, L. I. (2007). Innovativeness and organizational innovation in total quality oriented firms: The moderating role of market turbulence. Technovation, 27(9), 514-532.

Sarwoko, E., Surachman, Armanu, \& Hadiwidjojo, D. (2013). Entrepreneurial characteristics and competency as determinants of business performance in SMEs. International Organization of Scientific Research Journal of Business and Management, 7(3), 31-38.

Sekaran, U., \& Bougie, R. (2010). Research methods for business: A skill building approach (5th ed.). Chichester: John Willey \& Sons Ltd.

Slater, S. F., \& Narver, J. C. (1994). Does competitive environment moderate the market orientation-performance relationship?. The Journal of Marketing, 58, 46-55.

Stonebraker, P. W., \& Liao, J. (2004). Environmental turbulence, strategic orientation: Modeling supply chain integration. International Journal of Operations \& Production Management, 24(10), 1037-1054.

Suthar, B. K., Chakravarthi, T. L., \& Pradhan, S. (2014). Impacts of Job Analysis on Organizational Performance: An Inquiry on Indian Public Sector Enterprises. Procedia Economics and Finance, 11, 166-181.

Tsai, K. H., \& Hsu, T. T. (2014). Cross-Functional collaboration, competitive intensity, knowledge integration mechanisms, and new product performance: A mediated moderation model. Industrial Marketing Management, 43(2), 293-303.

Tsai, K. H., \& Yang, S. Y. (2013). Firm innovativeness and business performance: The joint moderating effects of market turbulence and competition. Industrial Marketing Management, 42(8), 1279-1294. 
Tsai, K. H., \& Yang, S. Y. (2014). The contingent value of firm innovativeness for business performance under environmental turbulence. International Entrepreneurship and Management Journal, 10(2), 343-366.

Ussahawanitchakit, P. (2011). Corporate Pro activeness, Business Experience, Environmental Complexity, and Firm Sustainability: Evidence from Information Technology Businesses in Thailand. Journal of International Business and Economics, 11(1), 66-74.

Varela, J. A., \& del Río, M. (2003). Market orientation behavior: an empirical investigation using MARKOR. Marketing intelligence \& Planning, 21(1), 6-15.

Venkatraman, N., \& Ramanujam, V. (1986). Measurement of business performance in strategy research: A comparison of approaches. Academy of management review, 11(4), 801-814.

Vorhies, D. W., \& Morgan, N. A. (2005). Benchmarking marketing capabilities for sustainable competitive advantage. Journal of marketing, 69(1), 80-94.

Waddock, S. A., \& Graves, S. B. (1997). The corporate social performance-financial performance link. Strategic management journal, 18(4), 303-319.

Wang, Y., Lo, H. P., \& Yang, Y. (2004). The constituents of core competencies and firm performance: evidence from high-technology firms in China. Journal of Engineering and Technology Management, 21(4), 249-280.

Zahra, S. A., Sapienza, H. J., \& Davidsson, P. (2006). Entrepreneurship and dynamic capabilities: a review, model and research agenda*. Journal of Management studies, 43(4), 917-955.

\section{Appendix A: Study Questionnaire}

$\mathrm{Mr} / \mathrm{Ms}$ Greetings

The Researcher aims to carry out a study entitled "A Structural Equation Model for analyzing the impact of Environmental Turbulence on Non-Financial Performance". Where the study mainly aims to investigate the impact of environmental turbulence on non-financial Performance at firms of Mobile telecommunications sector in Jordan.

\section{Personal \& Occupational Characteristics}

(1) Age

$$
\text { Less than } 30 \text { Years }
$$

From 35 - 39 Years

(2) Gendar

(3) Qualification

$$
\begin{array}{r}
\text { Diploma } \\
\text { High Diploma } \\
\text { Doctorate }
\end{array}
$$

(4) Experience

Less than 5 Years

From $11-15$ Years

(5) Managerial level
Manager

Head of Division
From 30 - 34 Years

40 Years and more

\section{Female}

Bachelor

Master

$$
\text { From 6-10 Years }
$$

16 Years and more 


\section{Section A: Environmental Turbulence}

Please show your opinion about the following clauses to determine the extent of agreement with what has been mentioned in each clause of the environmental turbulence clauses. $(1=$ strongly disagree; $5=$ strongly Agree $)$

\begin{tabular}{|c|c|c|c|c|c|c|}
\hline \multirow[b]{2}{*}{ No. } & \multirow[b]{2}{*}{ Items } & \multicolumn{5}{|c|}{ Answer alternatives } \\
\hline & & $\begin{array}{l}\text { Strongly } \\
\text { disagree }\end{array}$ & Disagree & Neutral & Agree & Strongly Agree \\
\hline \multicolumn{7}{|c|}{ Market Turbulence } \\
\hline 1 & $\begin{array}{l}\text { customers' preferences in the mobile } \\
\text { mobtelecommunications sector change quite a bit } \\
\text { overtime }\end{array}$ & & & & & \\
\hline 2 & $\begin{array}{l}\text { Our customers in the mobile telecommunications sector } \\
\text { tend to look for new products all the time }\end{array}$ & & & & & \\
\hline 3 & $\begin{array}{l}\text { Our customers are very price-sensitive, but on other } \\
\text { occasions, price is relatively unimportant }\end{array}$ & & & & & \\
\hline 4 & $\begin{array}{l}\text { We are witnessing demand for our products and services } \\
\text { from customers who did not deal with us previously. }\end{array}$ & & & & & \\
\hline 5 & $\begin{array}{l}\text { The needs of the new customers differ from the needs } \\
\text { required by our current customers }\end{array}$ & & & & & \\
\hline \multicolumn{7}{|c|}{ Technological Turbulence } \\
\hline 6 & $\begin{array}{l}\text { The technology in mobile telecommunications sector is } \\
\text { changing rapidly }\end{array}$ & & & & & \\
\hline 7 & $\begin{array}{l}\text { Technological changes provide big marketing } \\
\text { opportunities in our sector }\end{array}$ & & & & & \\
\hline 8 & $\begin{array}{l}\text { A large number of new product ideas have been made } \\
\text { possible through technological innovations }\end{array}$ & & & & & \\
\hline 9 & $\begin{array}{l}\text { Mobile telecommunications work within the competition } \\
\text { requires technological developments and adoptio of it }\end{array}$ & & & & & \\
\hline 10 & $\begin{array}{l}\text { It is difficult to predict the technological changes in } \\
\text { mobile telecommunications sector }\end{array}$ & & & & & \\
\hline \multicolumn{7}{|c|}{ Competition Intensity } \\
\hline 11 & $\begin{array}{l}\text { Competition in mobile telecommunications sector is very } \\
\text { intense }\end{array}$ & & & & & \\
\hline 12 & $\begin{array}{l}\text { There are many intense "promotion wars" in mobile } \\
\text { telecommunications sector. }\end{array}$ & & & & & \\
\hline 13 & $\begin{array}{l}\text { For anything that one competitor can offer to the } \\
\text { customers, others can match readily and provide } \\
\text { immediately. }\end{array}$ & & & & & \\
\hline 14 & $\begin{array}{l}\text { Price competition is a hallmark of mobile } \\
\text { telecommunications sector. }\end{array}$ & & & & & \\
\hline 15 & $\begin{array}{l}\text { One hears of a competitive move almost every day in } \\
\text { mobile telecommunications firms }\end{array}$ & & & & & \\
\hline
\end{tabular}




\section{Section B: Organizational Non-Financial Performance}

Please show your opinion about the following clauses to determine the extent of agreement with what has been mentioned in each clause of the Organizational non financial Performance clauses compared to competitors. $(1=$ Much Worse than competitors; 5 = Much Better than competitors)

\begin{tabular}{|c|c|c|c|c|c|c|}
\hline \multirow[b]{2}{*}{ No. } & \multirow[b]{2}{*}{ items } & \multicolumn{5}{|c|}{ Answer alternatives } \\
\hline & & $\begin{array}{r}\text { Much Worse } \\
\text { than } \\
\text { competitors } \\
\end{array}$ & $\begin{array}{r}\text { Worse than } \\
\text { competitors }\end{array}$ & $\begin{array}{r}\text { Same as } \\
\text { competitors }\end{array}$ & $\begin{array}{r}\text { Better than } \\
\text { competitors }\end{array}$ & $\begin{array}{r}\text { Much Better } \\
\text { than } \\
\text { competitors } \\
\end{array}$ \\
\hline \multicolumn{7}{|c|}{ Customer Satisfaction } \\
\hline 16 & \multicolumn{6}{|l|}{ Retaining valued customers } \\
\hline 17 & \multicolumn{6}{|l|}{ Delivering value to your customers } \\
\hline 18 & \multicolumn{6}{|l|}{ Delivering what your customers want } \\
\hline 19 & \multicolumn{6}{|l|}{ Overall customer satisfaction } \\
\hline \multicolumn{7}{|c|}{ Market Effectiveness } \\
\hline 20 & $\begin{array}{c}\text { Market share growth } \begin{array}{c}\text { relative to } \\
\text { competitors }\end{array} \\
\end{array}$ & & & & & \\
\hline 21 & Growth in sales revenue & & & & & \\
\hline 22 & Acquiring new customers & & & & & \\
\hline 23 & Increasing sales to existing customers & & & & & \\
\hline
\end{tabular}

